\title{
Cancer: Radiological Treatment and Research
}

$\mathrm{T}^{\mathrm{H}}$ HE radiological policy of the Medical Research Council immediately after the Great War was determined by its acceptance from the Ministry of Munitions in 1919 of about two and a half grams of radium element for the purposes of experimental and clinical research. Since then the Council has systematically helped the advance of radiology, especially in its relation to cancer, and from 1922 onwards, with only one omission, it has published yearly reports from research centres in the "Medical Uses of Radium" series. The current issue for $1937^{*}$ has just been published and maintains in every way the traditions of these publications. A larger section each year is devoted to pure experimental research. One of the chief values of this publication is that it gives a summary of the results of radium treatment of cancer in various parts of the body. The results are given as survival rates, and in many cases the data extend back over a period of ten years or more.

About the same time another valuable contribution, the "Report on Radium Beam Therapy Research", also under the ægis of the Council, has been published $\uparrow$. This report relates in detail the way in which a clinical investigation into the value of large radium units (five grams of radium element) was carried out. The research was begun in 1934 with one five-gram unit, and another similar unit was available in 1936. At the outset, it was decided to limit the research to cases of cancer of the mouth, pharynx and larynx, the reasons for this choice being that they are accessible to direct examination, and that adequate surgery is in many cases difficult and mutilating.

It is impossible here to refer to the many features which give the impression of work admirably planned and no less admirably carried out; there is scarcely a question that comes to the mind that is not answered in the text. It is a welcome sign in the radiological outlook to find a paragraph such as the following:

"It is already noteworthy that doses as large as $8,000 \mathrm{r}$ have failed to sterilize some growths, whereas 4,000 $\mathrm{r}$ has been successful in others. It would appear that there are many factors other than dosage which have a profound influence on the response of cancer to radiation."

Turning from radiological research and treatment of cancer to the policy that is to guide its development in the future, two publications call

- Medical Research Council. Special Report Series, No. 232 : Medica] Uses of Radium; Summary of Reports from Research Centres for 1937 . Pp. $48+2$ plates. (London: H.M. Stationery Office, 1938.) 18. net.

† Medical Research Council. Special Report Series, No. 231: Report on Radium Beam Therapy Research, 1934-1937. By Constance A. P. Wood L. G. Grimmett, T. A. Green and others. Pp. $77+$ for comment; one is the "Annual Report of the Radium Commission, 1937-1938"*, the other the text of a Cancer Bill introduced into the House of Commons on November 30 by the Minister of Health, Mr. Walter Elliot. The Bill is the result of the efforts made in the last ten years by those actively concerned in the radiological treatment of cancer. Whether it be an individual or a group or an organizing body, like the Council and Commission already mentioned, or a coordinated effort by the British Empire Caricer Campaign and King Edward's Hospital Fund, the result is the sum total of these efforts, and it is to show that radiological methods are of great value in the diagnosis and treatment of cancer. A national policy to ensure more facilities for cancer treatment is overdue, but none the less welcome. The main provision of the Cancer Bill is to establish a service under which, in every part of the country, modern facilities for diagnosis and treatment of cancer will be available. The Bill places an obligation on the major local authorities to consult with the Radium Commission and bodies representing voluntary hospitals and the local medical profession, and to make arrangements for securing the necessary facilities. The Bill provides for an Exchequer grant towards the cost of the new service. When the service is in full operation, the additional expenditure will amount to about $\mathfrak{£ 6 0 0 , 0 0 0}$ per annum for England and Wales, and $£ 100,000$ for Scotland.

A clause of the Bill provides for "loans to be made to the National Radium Trust for the purchase of additional quantities of radium. Provision is also made enabling money to be lent to the Trust under the section for the purchase of other radioactive substances and apparatus and appliances required for radiotherapeutic treatment. It is proposed that the moneys to be advanced to the Trust, not exceeding $\$ 500,000$ in all, shall be repayable to the Minister with interest by way of annuities spread over appropriate periods".

Only brief reference can be made to the annual report of the Radium Commission, which includes a statistical report. The outstanding feature of the report is the information upon the use of the bigger radium units, made possible by the provision of another 10 grams of radium. Units ranging from 1 to 3 grams of radium element are in use at no fewer than seven of the national centres throughout Great Britain.

The Government purchase is going to give * Ninth Annual Reports of the National Radium Trust and Radium 5883.) Pp. 63. (London : H.M. Stationery Offlce, 1938.) 18. net.
H. 
Great Britain a big interest in radium as a possession. This will inevitably entail continuous technical and chemical work, such as the filling, redistribution and concentration of radium in containers. The National Physical Laboratory has served the country well in physical measurements, but radium services have always been and will remain incomplete until a physical chemistry laboratory becomes part of the national radium and cancer service.
It is very doubtful whether any country of size and population of Great Britain is better supported and staffed in the fight against cancer, and to their credit it should be remembered that the voluntary hospitals have borne the brunt of radiotherapeutic research. It now remains to be seen how successfully individual efforts can be co-ordinated to the common good.

S. Russ.

\section{Scientific Centenaries in 1939}

\section{By Eng.-Capt. Edgar C. Smith, O.B.E., R.N.}

$\mathrm{O}^{\mathrm{N}}$ May 26, 1639, three hundred years ago, in the ancient convent of the Jacobins, in the historic Rue St.-Honoré, Paris, there passed away at the age of seventy-one years the refugee Italian philosopher Tomaso Campanella, one of those inquiring men of unquenchable spirit, who by their determination to destroy "those errors which had become venerable by antiquity" paved the way for the free exercise of thought and investigation which is one of the treasures of the world to-day. Born at the little town of Stillo, Calabria, on September 5, 1568, he was a contemporary of Kepler and Galileo, and like the latter he incurred the hostility of the Church, although a member of it. Owing to his political activities, he was kept in confinement in Naples by the Spanish Government for more than a quarter of a century, but he was able to write several books, among which was "An Apology for Galileo". He was nearly sixty years of age when set free, but even then was kept under close observation, and in 1634, when sixtyfive, he escaped from Rome to Marseilles. In France he was befriended by Louis XIII and Richelieu, and was given lodgings in the convent of the Jacobins in Paris.

The year 1639 also witnessed, not the birth or death of a famous astronomer, but the epochmaking astronomical observation of a transit of Venus, by the young Lancashire clergyman Jeremiah Horrocks. On Sunday, November 24, 1639 , in between his religious duties, Horrocks had the intense gratification of witnessing, as he had expected and laboured for, the passage of the planet across the sun's disk. His friend Crabtree at Broughton, near Manchester, through Horrocks, in the late afternoon of that Sunday, also caught a glimpse of the same spectacle. "Thus did two young men, cultivating astronomy together in a scate of almost complete seclusion in one of the northern counties of England, enjoy the privilege of witnessing a phenomena which human eyes had never before beheld, and which no one was destined again to see until more than a hundred years had passed away" (Grant). Hundreds of observers watched the transits of 1761 and 1769 , and those of 1874 and 1882, and it was through the interest aroused by that of 1874, that a tablet to Horrocks, with an inscription by Dean Stanley, was placed on the memorial to Newton's nephew, John Conduitt, at the west end of Westminster Abbey.

Cambridge had no chair of mathematics when Horrocks was an undergraduate at Emmanuel College, and it was not until 1663 that the Lucasian professorship was founded. The first occupant of the new chair was Barrow, the second was Newton, the third was Whiston and the fourth was Nicolas Saunderson, who died at the age of fifty-seven years on April 19, 1739. Saunderson had held the chair twenty-eight years, having been appointed to succeed Whiston, who in 1710 was deprived of his post owing to his religious opinions. At this time, mathematics at Cambridge may, as Prof. Turner said, have entered a dark century which it is difficult to contemplate, but assuredly Newton had no more devoted disciple than Saunderson. Blind from the age of a year, Saunderson owed his knowledge of mathematics to the patience and generosity of friends, one of whom, Joshua Dunn, took him to reside at Cambridge in 1707. Lord Chesterfield, who was at Cambridge in 1712-14, described Saunderson as a professor "who had not the use of his own eyes, but taught others to use theirs".

Contemporaries of Saunderson in Italy and France, who made contributions to physical science and who also died in 1739, were Eustachio Manfredi (1674-1739), the elder of the two Bolognese mathematicians and hydraulic engineers bearing that surname, and Charles Francois Du Fay (16981739), who repeated and extended Gray's electrical experiments and was the discoverer of two kinds of electricity which he named the vitreous and the resinous. He also noticed the discharging power of flames. Du Fay had first been a soldier, but 